\title{
Economic Growth, Structural Change and Productive Employment Linkages in India Did Market Transition Matter?
}

Aggarwal, Aradhna

\author{
Document Version \\ Accepted author manuscript \\ Published in: \\ South Asia Economic Journal \\ DOI: \\ $10.1177 / 1391561418761074$ \\ Publication date: \\ 2018 \\ License \\ Unspecified
}

Citation for published version (APA):

Aggarwal, A. (2018). Economic Growth, Structural Change and Productive Employment Linkages in India: Did Market Transition Matter? South Asia Economic Journal, 19(1), 64-85.

https://doi.org/10.1177/1391561418761074

Link to publication in CBS Research Portal

\section{General rights}

Copyright and moral rights for the publications made accessible in the public portal are retained by the authors and/or other copyright owners and it is a condition of accessing publications that users recognise and abide by the legal requirements associated with these rights.

\section{Take down policy}

If you believe that this document breaches copyright please contact us (research.lib@cbs.dk) providing details, and we will remove access to the work immediately and investigate your claim.

Download date: 26. Apr. 2023
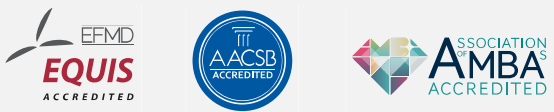


\section{Economic Growth, Structural Change and Productive Employment Linkages in India: Did Market Transition Matter?}

\section{Aradhna Aggarwal}

Journal article (Accepted manuscript*)

\section{Please cite this article as:}

Aggarwal, A. (2018). Economic Growth, Structural Change and Productive Employment Linkages in India: Did Market Transition Matter? South Asia Economic Journal, 191), 64-85. 001: 10.1177/1391561418761074

\section{DOl: https://doi.org/10.1177/1391561418761074}

Copyright [0 Research and Information २०18. Reprinted by permission of SAGE Publications.

* This version of the article has been accepted for publication and undergone full peer review but has not been through the copyediting, typesetting, pagination and proofreading process, which may lead to differences between this version and the publisher's final version AKA Version of Record.

Uploaded to CBS Research Portal: February 2019 


\title{
Economic Growth, Structural Change and Productive Employment Linkages in India: Did Market Transition Matter?
}

\author{
Aradhna Aggarwal \\ Professor, Indian Studies \\ Department of International Economics and Management \\ Copenhagen Business School \\ Porcelænshaven 24A, 1-4.sal \\ 2000 Frederiksberg \\ Mobile: +45 91455565 \\ Email: aradhna.aggarwal@gmail.com \\ aa.int@cbs.dk
}

\begin{abstract}
This paper presents a quantitative analysis of growth, structural change and employment linkages at the aggregate level and by sector under the state- and market-led regimes in India. The underlying objectives are: (a) to understand how economic liberalisation has affected the economic and labour market structures, and linkages thereof; and (b) to analyse how these dynamics have affected the generation of productive employment in the economy. The analysis is based on Shapley Decompositions. Our results suggest that the contribution of structural change in employment to growth declined drastically and secularly as the country transitioned to a high growth regime driven by globalisation. The sector level analysis indicates that employment opportunities are not being created in high productivity sectors and segments. Thus despite a high growth rate in GDP per capita and productivity-enhancing structural transformation in GDP, a vast population is still trapped in employment that cannot be qualified as productive employment. The study attributes it to trade-induced economic specialisation in high skilled services accompanied with weakening of internal inter-sectoral linkages. The paper makes a strong case for strategic government intervention to broad base structural change for generating productive employment, which is at the core of poverty reduction.
\end{abstract}

Key words: Economic Growth, Globalisation, Employment, Shapley decomposition, Structural change, India

JEL classification: E24, O14, O4 


\section{Economic Growth, Structural Change and Productive Employment in India: Did Market Transition Matter?}

\section{Introduction}

There is a general consensus that the unprecedented growth in GDP in many developing countries in the post 1990 period has not been accompanied by commensurate growth in employment and that the employment elasticity of growth has declined drastically after liberalization. This has raised concerns among policy makers about 'jobless growth' as a major obstacle for the poor to benefit from the positive growth performance. According to an emerging economic thinking however what matters is 'productive (decent)' employment and not 'employment' per se. The 'New Structural Economics' as it has come to be called is based on the premise that labour markets in developing countries are usually segmented between 'more productive' and 'less productive' jobs (Hull, 2009:69). It emphasizes that economic growth that is accompanied with increased employment opportunities in 'more productive' sectors is more likely to be sustained and can alleviate poverty. The notion of productive employment is associated with growth (and productivity)-enhancing structural change, decent earnings and in turn poverty reduction. With the advent of this new thinking there has been growing interest in the analysis of structural change in employment (see, Aggarwal and Kumar, 2012; Lin, 2001; Naude et al, 2014, for survey). This has motivated emergence of a body of empirical literature with a focus on systematic unbundling of the relationship between economic growth on the one hand and, employment, and structural change in employment on the other at the aggregate level and by sector (see, for instance, Gutiérrez et al. 2009; Hull , 2009; Kucera and Roncolato, 2012; Macmillan and Rodrik, 2011; Van Ark and 
McGuckin, 1999: Van Ark and Timmer, 2000). However, while doing so, most studies process data at one point in time and draw long run inferences from cross sectional results. Little is explored about the underlying mechanisms, which establish linkages between growth, employment and structural change and how these mechanisms are affected by the process of globalisation. The present study contributes to this literature in two ways. First, it identifies the mechanisms underlying the growth and structural change dynamics and formulates the key proposition underscoring the importance of economic liberalisation as a key determinant of changes in these dynamics. Second, it investigates these dynamics in the context of India for different policy regimes, using Shapley's decomposition of growth in GDP per capita to validate the core proposition. The three research questions are: how does market transition affect the process of structural change in employment? Has globalisation impacted on the process of structural change in employment? What has been India's experience in this regard?

The past 65 years of India's growth history have been marked by two broad policy regimes: 'stateled' and 'market led'. In each policy regime two to three distinct phases of policy approaches can be discerned (Aggarwal and Kumar, 2012). The analysis presented in the study is conducted for each of the policy phases for which data are available within an overarching framework of the state- and market led regimes. The 'Shapley's approach disentangles GDP growth per capita into employment and productivity effects at the aggregate level. It identifies the contribution of each sector to growth, employment and productivity; most importantly it isolates the contribution of structural change in employment to economic growth. There has been an increasing use of the JOGG tool developed by the World Bank in analyzing these relationships (Ajakaiye, 2016; Bbalme, 2016; Byiers et al 2015; Malunda, 2013). This tool offers an elaborate analysis of 
employment and productivity effects on GDP growth per capita at the aggregate and sector levels and productive employment.

To perform these decompositions, I sourced data on GDP from National Accounts Statistics provided by the Central Statistics Office (CSO) in India. Employment statistics is based on the quinquennial NSS rounds of 'employment and Unemployment' starting from 1972-73. I use five

of these rounds corresponding to years, 1972-73, 1983, 1993-84, 2004-05, and 2011-12. They are selected such that the period between any two successive rounds corresponds to a particular policy phase.

The rest of the study is organised into 5 sections. Section 2 presents the theoretical underpinning of the analysis. Section 3 analyses economic growth, employment growth and structural change in the Indian economy using descriptive statistics. Section 4 describes the methodology for establishing the relationship between the key variables and discusses empirical results. Finally, Section 5 discusses policy implications of the analysis.

\section{Economic Growth, Structural Change and Productive Employment: The New Structuralist Perspective and Challenges of Globlisation}

Economic growth in developing countries is intrinsically tied to dynamics of its production structures, which bring about growth through the expansion of value-added and employment in higher productivity sectors at the cost of the lower productivity ones (see, Aggarwal and Kumar, 2012; Islam and Kucera, 2014 for literature review). When labour and other resources move from less productive to more productive activities, the economy grows even if there is no productivity 
growth within sectors (Mcmillan and Rodrik, 2011). Structural change thus removes constraints from productivity growth. Timmer and Szirmai (2000) coined the term 'structural change bonus' for this.

According to conventionally accepted economic thinking, development first shifts labour from primary to secondary sector and then eventually leads to the majority of the labour force working in the service sector. Typically, in a developing economy labour productivity in primary sectors is relatively much lower than in non-primary sectors. It means that a shift of resources from primary to non-primary sectors is growth enhancing. Among non-primary sectors manufacturing contributes disproportionately to productivity growth regardless of geographic location and country (see, Rodrik, 2011). This is because the manufacturing sector offers a large scope of capital accumulation, economics of scale, and embodied and disembodies technological progress, all of which are directly related with productivity growth. While a shift from agriculture to manufacturing is considered crucial for growth and economic development, the sequential change from industry to service may not always contribute to steady growth and productivity. In his seminal paper, Baumol (1967) proposes the idea of 'structural burden of tertiarisation' termed as the 'Baumolian cost disease' hypothesis. He argues that the resource reallocation of productive manufacturing industries towards unproductive or stagnant services in particular, education, health, administrative and community services might eventually dampen productivity, increase costs and prices and slow down aggregate growth (Hartwig, 2012; Nordhaus, 2008 for discussion).

It is however observed that with the process of globalization and breakthroughs in information and communication technology (ICT), the nature of the service sector has also altered. It is no longer 
dominated by non-tradable low-productivity Baumolian services. The ICT revolution has removed obstacles to trade in services and the process of globalization has propelled expansion of trade in services. More and more personal services are being traded fuelling global trade in services (Blinder, 2006). These ICT enabled dynamic services such as financial services, software services, and transport and logistics are termed high-productivity services and are distinguished from the low productivity ones (education, health, administrative and community services) (de Vries 2010; Triplett and Bosworth 2003). This dichotomy is generally used to argue that manufacturing may not be critical for driving growth and that the reallocation of labour towards modern dynamic and IT enabled services can also stimulate productivity and economic growth (Ghani \& O'Connell, 2014). Many discard this dichotomy in services and point out that in general, productivity growth has been higher in services than in manufacturing (Bernard and Jones, 1996; Gouyette and Perelman, 1997). Hull (2009) argues that each economic sector including 'manufacturing' and 'agriculture' has both, the 'high' and 'low' productivity segments. The segments, which are exposed to international competition, are driven by high productivity growth; low productivity levels and growth on the other hand mark non-tradable or informal segments. Therefore the distinction between the high and low productivity sectors is getting blurred; much depends on the exposure to trade.

A critical question is what drives the structural change in GDP and employment from low to high productivity segments/sectors with economic growth. Coventionally, it is explained by differences in the income elasticity of demand across sectors with its being the lowest for agricultural products and largest for services (Kaldor, 1966). With rising levels of income, the demand for agricultural products relatively declines and that for industrial goods increases, and after reaching a reasonably high level of income, demand for services increases sharply. The shares of different sectors in the 
national product get affected by the changes in the pattern of demand, which, in turn, are reflected in the structural change in employment (e.g., Chenery and Taylor, 1968). The underlying assumption is twofold: one, consumption expenditures are closely linked with production within an economy; and two, changes in production shares affect labour shares as well. In other words, growing incomes generate demand for goods and services across sectors which induces production in the economy to meet this demand. Expansion in production generates demand for labour which induces commensurate changes in employment patterns. This means that the demand side signals are translated into efficient supply side responses through inter-sectoral interdependence. For instance, productivity growth in the agricultural sector is a prerequisite for industrial development in the early stages of growth. It not only releases labour from agriculture but also keeps the prices of food products under control for the process of industrialization to proceed efficiently and supplies some critical raw material for agro-based industries. But, the relationship is not one-way. Agriculture in turn depends on industry and services for sustaining its own growth. Similarly, industry and services are also interconnected through forward and backward linkages. This connectedness is the driver of structural change in both GDP and labour markets.

Globalisation may snap these linkages by integrating economies with global markets, affecting the process of structural change (Alvarez-Cuadrado et al, 2017; Uy et al. 2013 for structural change modeling in an open economy). The tradable sectors are marked by high productivity due to their integration with the global value chains. They can play a crucial role in driving growth and productivity-enhancing structural change in GDP. But, the trade-induced shifts in GDP from low to high productivity sectors may not be accompanied by commensurate changes in the employment structure because the tradable sectors, may actually be generating few jobs, putting little pressures on other sectors to improve productivity and release labour. The orthodox trade theorists argue 
that the expanding export markets more than offset the high productivity effect and generate increasing demand for labour. But much depends on the factor intensity of the tradable sector. There is evidence of developing countries at early stages of development specialising in agricultural commodities, mineral based sectors or skill intensive services. In most cases, these .countries tend to face a 'resource curse like situation' where the high productivity tradable sectors hamper the growth of other sectors rather than reinforce it. While there is no pressure on other sectors to improve productivity, there are pressures on them to raise wages to compete for labour creating a situation of cost disease, making other sectors uncompetitive and directing domestic demand to international markets. Growth in tradable sectors may not thus stimulate growth and employment in other sectors due to the possibility of importing goods and services discouraging forward linkages as well (UNCTAD, 2004; OECD 2015).

With the breaking down of the self-reinforcing process of structural change, many developing countries appear to have entered into paradigms of the vast chunk of population stuck in low productivity jobs with GDP growth driven by high productivity sectors linked globally. Thus, it is proposed here that growth and structural transformation of GDP may not be accompanied with productivity-enhancing structural change in employment,, which is crucial for poverty reduction. . In what follows, I first investigate the patterns of growth and sectoral composition of GDP and employment by policy regime in India.

\section{Macroeconomic Policy Regimes, Economic growth and employment in India}

\subsection{Policy regimes and GDP Growth Rates}

The State-led Policy Regime: 
The first thirty years of India's post independence period 1951-1980 were associated with the state-led model of growth with the public sector occupying the commanding heights of the economy. The centerpiece of this model was the promotion of import-substitution based industrialisation with a particular emphasis placed on basic and heavy industries. This regime was implemented through a combination of planning and licensing for resource management, on the one hand; and heavy public investment in strategic industries, higher education, and training and R\&D labs, on the other (Aggarwal, 2001). The strategy paid off and produced an unprecedented spurt in industrial growth and hence economic growth during the 1950s and early 1960s as shown in Table 1.

Table 1: GDP growth rate: $1950-51$ to $2011-12$

\begin{tabular}{|c|c|c|c|c|c|}
\hline Policy Regime & Years & $\begin{array}{l}\text { Policy } \\
\text { orientation }\end{array}$ & Policy objectives & $\begin{array}{l}\text { Average } \\
\text { annual growth } \\
\text { rate }(\%)\end{array}$ & $\begin{array}{l}\text { Standard } \\
\text { deviation }\end{array}$ \\
\hline \multirow{2}{*}{$\begin{array}{l}\text { State led policy } \\
\text { regime }\end{array}$} & $\begin{array}{ll}1950-51 & \text { to } \\
1964-65\end{array}$ & \multirow{2}{*}{$\begin{array}{l}\text { Import } \\
\text { substituting } \\
\text { regime }\end{array}$} & Growth & 4.091 & 2.55 \\
\hline & $\begin{array}{ll}1965-66 & \text { to } \\
1979-80 & \end{array}$ & & $\begin{array}{l}\text { Growth with social } \\
\text { justice and self- } \\
\text { reliance }\end{array}$ & 2.93 & 4.18 \\
\hline \multirow{3}{*}{$\begin{array}{l}\text { Market led } \\
\text { regime }\end{array}$} & $\begin{array}{ll}1980-81 & \text { to } \\
1991-92 & \end{array}$ & $\begin{array}{l}\text { Cautious } \\
\text { reforms }\end{array}$ & $\begin{array}{l}\text { Growth with } \\
\text { efficiency }\end{array}$ & 5.39 & 2.22 \\
\hline & $\begin{array}{l}1991-92 \\
2003-04\end{array}$ & \multirow[t]{2}{*}{$\begin{array}{l}\text { Outward } \\
\text { oriented regime }\end{array}$} & $\begin{array}{l}\text { Growth with } \\
\text { international } \\
\text { competitiveness }\end{array}$ & 6.2 & 1.46 \\
\hline & $\begin{array}{ll}2004-05 & \text { to } \\
2011-12 & \\
\end{array}$ & & $\begin{array}{ll}\text { Growth with } \\
\text { inclusion }\end{array}$ & 8.3 & 1.40 \\
\hline
\end{tabular}

Source: Own calculations based on Central Statistical Organisation, Ministry of Statistical Planning and Implementation, India database

In the late 1960s, however, explicit policy measures emphasizing growth with equity and self reliance were initiated. Government regulations were tightened on almost every aspect of the economy with numerous restrictions on trade, foreign investment, technology transfers and scale economies. At the same time. a variety of redistributive programmes were launched to generate employment and alleviate poverty; special attention was given to industrially backward regions, and tax rates were raised to curb the consumption of the rich in favour of the poor. Both pubic 
and private investment fell during this period, and the country faced decelerating growth rates as shown in Figure 1..

\section{The Market-led Regime}

A turning point occurred in 1980-81 when the "state-led model of growth" was abandoned in favour of a "market-led growth strategy". This policy phase was characterised by gradual reforms introduced essentially to deregulate industries, capacity expansion, and technology transfers (Virmani, 2005). This phase saw recovery in the GDP growth due to both policy changes and external factors. It crucially featured a pick-up in GDP growth supported by all the three sectors. Industry grew at an average growth rate of $6.1 \%$ in contrast to $3.9 \%$ growth during $1965-80$, owing to improvements in both the rate of investment and productivity. The agricultural sector witnessed favourable growth rates due mainly to the diffusion of private tube-wells, agricultural diversification towards more remunerative commodities and technological breakthroughs (Joshi et al., 2006). Within services, there had been a noticeable shift away from low productivity services namely community services and public administration to high productivity business and financial services followed by trade and hotels, which fueled growth further.

In the early 1990s, sweeping reforms were introduced in the Indian economy to assign the private sector commanding heights and give a major thrust to economic growth (Aggarwal and Kumar, 2012; Aggarwal, 2001). Starting 2003-04, the economy entered into an unprecedented growth phase. While the economy grew at an average annual rate of almost 7\% during 1993-94 to 201112 , the rate of growth had been as high as $8.3 \%$ between $2004-05$ and $2011-12$. It marked a turning point and a phase of unprecedented growth. This was led by explosion in the service sector which started growing rapidly towards the end of the 1990s especially with the rise of growing exports of software and ICT-enabled services following the success of Indian companies in fixing the Y2K 
bug. While the growth of the modern and dynamic services namely transport, communication, financial and business (including the software and related) services exploded, the traditional trade, hotels, community, and public administration services have shrunk in importance. The manufacturing sector barely managed to maintain its share but the infrastructure and mining sectors could not match the growth of GDP and exhibited declines in their shares. These retrogressive patterns could have had serious effects on the growth potential of the country. But, progressive shifts in the structure of services more than offset these negative effects on growth.

Overall, Table 1 shows that each successive period in the market regime is marked by a relatively more liberalized policy regime and is associated with a higher annual compound growth rate in GDP and GDP per capita and lower variability. Thus, acceleration in economic growth and policy regime reforms coincide in the Indian context.

\subsection{Policy Regimes and Employment}

During the first decade and a half of development planning in India, unemployment was not expected to emerge as a major problem by the policy makers (Second Plan document, 1956). Growth, it was assumed, would automatically translate into job creation (Okun's Law). As a result, there are no official estimates on employment generation for the period before 1972-73. This situation began to change during the 1970s. Several employment generation and poverty alleviation programmes were launched and to gauge the problem of unemployment in the country, the first country-wide survey on employment and unemployment was conducted by the National Sample Survey Organisation (NSSO) in 1972-73. Between 1972 and 2012 eight quinquennial 
NSSO surveys on unemployment and unemployment were conducted. They provide extensive information on employment and unemployment situation in India.

Using these surveys, I estimated employment rates for four time periods, 1972- 73 to 1983,1983 to $1993-94$, 1993-94 to 2004-05, and 2004-05 to 2009-2010 and presented in Table 2. Each of these periods covers one policy phase that India has witnessed over the period from 1972 to 2012. While 1972-73 to 1983 corresponds to the policy phase of social justice and self reliance under stated -led regime, the period between 1983 and 1993-94 represents the first phase of the market regime. The period from 1993-94 to 2004-05 is the second phase of market regime with globalisation ushering in, and that from 2004-05 to 2011-12 represents the phase of accelerated growth.

Table 2: Employment 1993-94 to 2011-12 (\%)

\begin{tabular}{|c|c|c|c|c|}
\hline & $\begin{array}{l}1972-7 \\
3 \text { to } \\
1983\end{array}$ & $\begin{array}{l}1983 \text { to } \\
1993- \\
94\end{array}$ & $\begin{array}{ll}1993-94 & \text { to } \\
2004-05 & \end{array}$ & $\begin{array}{l}2005- \\
2012\end{array}$ \\
\hline Annual compound growth rate of work force & 2.40 & 2.11 & 1.85 & 0.42 \\
\hline Annual compound growth rate of labour force & 2.43 & 2.11 & 1.89 & 0.41 \\
\hline Annual compound growth rate of Unemployment & 4.00 & 2.20 & 3.70 & 0.1 \\
\hline Employment elasticity & 0.52 & 0.47 & 0.30 & .05 \\
\hline Unemployment rate & 1.6 & 1.9 & 2.3 & 2.2 \\
\hline
\end{tabular}

Source: Author's estimates based on the selected NSS Rounds

It may be seen the employment growth rate was at the peak level in the 1970s (Table 2). Since then, there has been a trend towards decline in employment growth indicators. The acceleration in economic growth was accompanied by a continuous decline in the employment growth rate from $2.4 \%$ per annum in the 1970 s to $0.4 \%$ during the period of unprecedented economic growth i.e. between 2004-05 and 2011-12. Over 2005-2012, only 13 million new jobs were added at the rate 
of $0.4 \%$ per annum. Apparently, the employment elasticity declined continuously from 0.3 during 2000-2005 to 0.05 during 2005-12. This led to concerns among policy makers over the delinking of growth and employment ('jobless' growth). But it must be noted that the unemployment rate actually declined in the high growth phase. While focusing on the quality of employment, this study will explore the reason for this paradox.

\subsection{Policy Regimes, and Structural Changes in GDP and Employment}

Table 3 presents GDP shares of three broad sectors: agriculture, industry and services. It shows that the Indian economy experienced massive transformation in the composition of GDP over the years since 1951-52. During the first policy phase of the state-led regime, industry-led growth strategy resulted in a decline of the agricultural share and increase in that of the industry. The spurt in industrial growth drove growth in the demand for services as well, in particular trade, hotel, transport and communication services.

Table 3: Sectoral composition of GDP for selected years between 1951-52 and 2009-10 (\% share)

\begin{tabular}{|c|c|c|c|c|c|c|c|}
\hline & $\begin{array}{l}1951- \\
52\end{array}$ & $\begin{array}{l}1965- \\
66\end{array}$ & $\begin{array}{l}1972- \\
73\end{array}$ & $\begin{array}{l}1983- \\
84\end{array}$ & $\begin{array}{l}1993- \\
94\end{array}$ & $\begin{array}{l}2004- \\
05\end{array}$ & $\begin{array}{l}2009- \\
10\end{array}$ \\
\hline Agriculture, forestry \& fishing & 52.6 & 41.1 & 39.1 & 35.3 & 28.3 & 19.0 & 14.6 \\
\hline Mining \& quarrying & 2.1 & 2.6 & 2.4 & 2.9 & 3.3 & 2.9 & 2.3 \\
\hline Manufacturing & 9.3 & 13.4 & 13.7 & 14.8 & 14.6 & 15.3 & 15.9 \\
\hline Electricity, gas \& water supply & 0.3 & 0.8 & 1.2 & 1.6 & 2.2 & 2.1 & 2.0 \\
\hline Construction & 5.4 & 7.9 & 7.9 & 6.8 & 6.7 & 7.7 & 7.9 \\
\hline Secondary & 17.1 & 24.7 & 25.2 & 26.1 & 26.8 & 27.9 & 28.1 \\
\hline Trade, hotels \& restaurants & 8.6 & 10.9 & 10.9 & 12.0 & 12.6 & 16.1 & 16.4 \\
\hline Transport, storage \& communication & 2.7 & 3.7 & 4.1 & 5.0 & 5.5 & 8.4 & 10.2 \\
\hline $\begin{array}{l}\text { Financing, insurance, real estate } \& \\
\text { business services }\end{array}$ & 8.5 & 7.9 & 8.1 & 9.1 & 13.3 & 14.7 & 17.2 \\
\hline $\begin{array}{l}\text { Community, social \& personal } \\
\text { services }\end{array}$ & 10.5 & 11.6 & 12.6 & 12.5 & 13.5 & 13.8 & 13.6 \\
\hline Tertiary & 30.3 & 34.2 & 35.7 & 38.6 & 44.9 & 53.0 & 57.3 \\
\hline
\end{tabular}

Source: Author's calculations based on the Central Statistical Organisation data 
However, during the mid-1960s, when there was transition in the policy focus from growth to social justice and welfare, public investment in productive activities decelerated and the industry started stagnating. A significant proportion of the public sector outlay was diverted to nondevelopment expenditures in the form of subsidies and other welfare programmes pertaining to direct poverty removal. As a result, 'low productivity' services such as administrative and community services (including defense consequent upon three wars) registered rapid growth pushing up the share of the service sector in GDP. This marked the beginning of the serviceoriented structural change in the Indian economy (see Aggarwal and Kumar, 2012).

The market driven policy regime, starting 1980, further reinforced the service sector growth. However, unlike the previous one, this phase of service growth was not led by low productivity services. Rather, it was driven by dynamic services namely, transport, communication, business, and financial services. This period coincided with the onset of ICT revolution due to technological advancement in this sector. India moved into the new activity drawing on a large pool of underemployed skilled labour which was created due to India's education and science and technology policy adopted during the regulated regime with a view to promote heavy industrialisation. In the globalized era of the post 1990 period, India's competitive advantages in services further strengthened ${ }^{1}$ and led to explosion in the service sector in India. While services increased their share in GDP unprecedentedly, the share of the manufacturing sector remained almost stagnant. The infrastructure and mining sectors exhibited declines in their shares.

\footnotetext{
${ }^{1}$ It could be attributed to deregulation of the telecommunication sector, technological enhancements in communication technologies and the rise of exports of software and ICT-enabled services following the success of Indian companies in fixing the Y2K bug
} 
Table 4: Sectoral composition of employment for selected years between 1951-52 and 200910 (\% share)

\begin{tabular}{|l|r|r|r|r|r|r|}
\hline & 1951 & 1972 & 1983 & 1994 & 2005 & 2012 \\
\hline Primary Sector & 74 & 73.92 & 68.59 & 63.98 & 56.3 & 48.9 \\
\hline Mining \& Quarrying & & 0.43 & 0.61 & 0.69 & 0.56 & 0.54 \\
\hline Manufacturing & & 8.87 & 10.66 & 10.63 & 12.27 & 12.6 \\
\hline Utilities & & 0.16 & 0.28 & 0.4 & 0.27 & 0.52 \\
\hline Construction & & 1.84 & 2.24 & 3.24 & 5.69 & 10.6 \\
\hline Secondary Sector & 10 & 11.3 & 13.79 & 14.96 & 18.79 & 24.26 \\
\hline Trade, Hoteling etc. & & 5.11 & 6.35 & 7.59 & 10.89 & 10.96 \\
\hline Transport \& Communication & & 1.77 & 2.49 & 2.87 & 4.08 & 4.83 \\
\hline $\begin{array}{l}\text { Financing, Insurance, Real estate \& } \\
\text { Business Services }\end{array}$ & & 0.51 & 0.83 & 0.97 & 1.71 & 1.66 \\
\hline Community, social and personal serv. & & 7.39 & 7.96 & 9.64 & 8.24 & 9.41 \\
\hline Tertiary Sector & 16 & 14.78 & 17.63 & 21.07 & 24.92 & 26.86 \\
\hline
\end{tabular}

Source: Author's estimates based on the selected NSS Rounds

Differential growth of GDP among different sectors of the economy was expected to bring about changes in the structure of employment also. But, as shown in Table 4, the GDP growth process and a dramatic structural change in its composition, involving a shift from the primary sectors into services, has not entailed an equally dramatic change in the employment structure in the country. Agriculture, which contributes 14\% of GDP remains the largest employer absorbing almost half of the work force. On the other hand, services that contribute almost $58 \%$ of the GDP absorb only $26.6 \%$ of the workforce. Despite the rapidly growing shares of 'dynamic services' in GDP, most service sector labour force remains trapped in 'trade', and 'community and administrative services', the so called 'low productivity' sectors. The share of industry in employment more than doubled from $11.3 \%$ in $1972-73$ to $24.6 \%$ in $2011-12$, but it was mainly due to increasing employment in construction. Construction, which increased its share in total employment from around $2 \%$ in $1972-73$ to over $10.5 \%$ by $2011-12$, has emerged as a major employer in the country. Manufacturing, the share of which remained stagnant in GDP, increased its share in employment 
slowly and erratically. 'Utilities' do not show perceptible changes in terms of employment shares; mining on the other hand has experienced a continuous decline since 1993-94. In what follows I shall investigate, using Shapley Decompositions, whether the structural change in employment has been productivity enhancing, and how it contributed to GDP growth.

\section{The Relationship Between GDP Growth and Structural Change: Shapley Decompositions}

Shapley decompositions disentangle growth in GDP per capita into two components: growth associated with GDP per worker (productivity effect) and growth associated with changes in employment (employment or work force participation rate effect) at the aggregate level and by sectors. The latter is further decomposed into two components: growth associated with changes linked to variations in output per worker within sectors ( intra-sectoral productivity) and changes linked to sectoral relocation of workers across sectors. The latter is of particular interest to us.

The decompositions are based on the JOGG methodology provided by the World Bank. Byiers et al (2015) have used this tool in the context of analysing economic structural transformation in several countries from Latin America, Africa, and Asia. It has also been used to analyse the incidence of jobless growth in Uganda (Bbaale 2013), Rwanda (Malunda 2013) and Nigeria (Ajakaiye, et al, 2016). The present study uses this tool to analyse the impact of market transition on growth, employment and structural change relationships in India. In what follows, we discuss the method and results from each step of decomposition.

\subsection{Aggeregate Analysis}


The GDP per capita income $Y / N=y$ can be expressed as:

$$
\frac{Y}{N}=\frac{Y}{E} * \frac{E}{A} * \frac{A}{N} \ldots \ldots
$$

where $\mathrm{Y}$ is total Value Added, $\mathrm{E}$ is total employment, $\mathrm{A}$ is the labour force and $\mathrm{N}$ is total population. Thus, $\mathrm{Y} / \mathrm{N}$ is GDP per capita, $\mathrm{Y} / \mathrm{E}$ is total output per worker, $\mathrm{E} / \mathrm{A}$ is the employment rate, i.e. the share of work force in total labour force and $\mathrm{A} / \mathrm{N}$ is the labour force participation rate. Equation (1) can be rewritten as,

$$
y=\omega * e^{*} a
$$

This implies that the total change in per capita GDP will be the sum of the growth attributed to each of its components $\omega, e$, and a, i.e.

$$
\frac{\Delta y}{y}=\bar{\omega} \frac{\Delta y}{y}+\bar{e} \frac{\Delta y}{y}+\bar{a} \frac{\Delta y}{y}
$$

Or,

$$
\Delta y=\bar{\omega}^{*} \Delta y+\bar{e}^{*} \Delta y+\bar{a} * \Delta y
$$

Where, $\bar{\omega} * \Delta y$ represents growth per capita linked to productivity change; $\bar{e} * \Delta \mathrm{y}$ is growth consistent with changes in the employment rate, and $\bar{a} * \Delta y$ is the amount of per capita growth linked to labour force changes. The contribution of each component needs to be interpreted as a counterfactual scenario in which all other components in each sector remain unchanged.

There may be several ways in which this equation can be estimated depending upon the assumption regarding the base year of the three parameters. Shapley decomposition considers all possible alternatives and then makes a weighted average of each ( see, formulas A.1 to A.3 in Appendix).

Growth and Employment effects 
Our aggregate results presented in Table 5 show that GDP per worker has been the dominant driver of growth across all policy regimes. Its contribution to growth increased continuously from $92 \%$ during the protective regime of $1972-83$ to over $100 \%$ by $2005-12^{2}$. In contrast, the employment effect ( col. 4), which contributed around 7\% of the GDP per capita during the 1970s, increasingly diminished as the economy transitioned from a regulatory to a market-led regime. In the high growth period of 2005-12, employment effect turned negative and its contribution was $-19 \%$. This means that had GDP per worker remained constant, changes in the work force participation rate would have actually contracted GDP growth per capita growth by $19 \%$.

Table 5: Decomposition of growth per capita 1972-2012: Aggregate level (\%)

\begin{tabular}{|c|c|c|lc|cc|}
\hline Year & $\begin{array}{c}\text { Contributio } \\
\mathrm{n} \text { of changes } \\
\text { in } \\
\text { Employmen } \\
\text { t rate (\%) }\end{array}$ & $\begin{array}{c}\text { Contributio } \\
\mathrm{n} \text { of } \\
\text { changes in } \\
\text { labour force } \\
\text { participatio } \\
\mathrm{n} \text { rate }(\%)\end{array}$ & $\begin{array}{l}\text { Contributio } \\
\mathrm{n} \text { of changes } \\
\text { employment } \\
(\%)\end{array}$ & $\begin{array}{c}\text { Contributions } \\
\text { of Inter- } \\
\text { sectoral Shifts } \\
(\%)\end{array}$ & $\begin{array}{c}\text { Contribution } \\
\text { s of changes } \\
\text { in intra- } \\
\text { sectoral } \\
\text { productivity }\end{array}$ & \\
\hline & 1 & 2 & 3 & 4 & 5 & $6=3+4$ \\
$+1973-1983$ & -1.13 & 8.25 & 7.12 & 51.15 & 41.73 & 100 \\
\hline $1983-1994$ & -0.09 & 0.10 & .01 & 32.37 & 67.63 & 100 \\
\hline $1994-2005$ & -0.91 & 0.90 & -.01 & 32.05 & 67.96 & 100 \\
\hline $2005-2012$ & 0.13 & -19.20 & -19.07 & 15.92 & 103.16 & 100 \\
\hline
\end{tabular}

Source: Author's estimates based on the selected NSS Rounds

To further probe the link between growth and employment, I decomposed employment effects into the employment rate (share of employment in labour force) and labour force ( share of labour force in population) effects. The former shows absorption of labour force into employment (deepening of labour market) while the latter manifests expansion in labour force (expansion of labour

\footnotetext{
${ }^{2}$ Since each effect is partial assuming the other constant, it can exceed $100 \%$. It implies that the productivity per worker grew faster than the GDP growth per capita.
} 
market). The results reveal that contrary to the expectations, the employment rate effect ( col. 1) was actually negative during the 1970s, which means that everything else remaining the same, a decline in the employment share of labour force would have contracted GDP per capita. This was despite the fact that a number of employment generation programmes were initiated in the 1970s as part of the poverty combat strategy. The negative employment rate effect was however more than offset by expansion in the labour force ( col.2), ensuring a positive employment (work force) effect. It means that the expansion in jobs fell short of expansion in the labour force during this period. As the economy liberalized in the 1980s, the employment rate effect started rising gradually. During growth acceleration of the 2000s, the employment rate effect turned positive and contributed $0.15 \%$ to growth in GDP per capita. But, this was accompanied by a large negative labour force effect, which turned the overall employment effect negative. Everything else remaining constant, contraction in the labour force participation rate alone would have reduced the growth in GDP per capita by almost $20 \%$. Apparently, it was contraction in the labour force that was responsible for a negative employment effect of the post 2000 period. Three explanations may be offered for the decline in the labour force participation rate (LFPR). First, dramatic growth in skill intensive high productivity services has led to an increase in returns on education with the wage rate getting skewed in favour of skilled labour. This has resulted in a sharp increase in tertiary sector enrollment. The enrollment ratio has increased from $9.5 \%$ in 2000 to $25.5 \%$ in 2014 (UNESCO website). Second, with acceleration in the growth of per capita income since the 1980s, female participation rate has exhibited a tendency to decline. Typically, at low levels of income, women work gainfully for their and their family's survival. With a rise in income levels, they feel less pressured to work and therefore withdraw from the workplace to return again in high productivity activities, as development progresses (Boserup, 1970). Third, there have been 
demographic changes with economic growth. These are for instance the decline in the population growth rate and change in the age structure (Bhalla and Kaur, 2011; Shubhanil, 2011). The contraction in the labour force is thus an outcome of the growth process that was triggered in the 1980s and accelerated with the process of globalisation. The declining labour force participation rate could not be offset by a sufficiently large increase in the employment rate ( or the number of jobs) in the 2000s. As a result, despite an increase in the employment rate with acceleration in the GDP growth, employment effects (the worker-population ratio) turned negative.

The above results have three implications. First, the overall employment effect has never been a major force driving growth in India since the 1970s. Second, this effect has become negative over time because of the decline in the labour force participation rate while the employment rate has shown an upward movement. Third, the latter is rather small in the Indian context. This is because most of the population has very low incomes and cannot afford to remain unemployed. A large fraction of the working-age population gets absorbed in agriculture or other informal and selfemployment activities It is therefore important to understand the quality of jobs where they are absorbed across different policy regimes.

\section{GDP growth per capita and productivity effects: The quality of jobs}

Equation (6) shows that the total output per worker is a weighted sum of output per worker in all sectors, where the weights are the employment share of each sector. This equation is further decomposed into 'within sector' and 'inter-sectoral productivity' effects (see Formulas 4 and 5 in the appendix). It may be noted that relocation of workers across sectors can increase average output per worker if a larger share of workers becomes employed in higher productivity sectors. 


$$
\frac{Y}{E}=\sum \frac{Y_{i}}{E_{i}} * \frac{\bar{E}_{i}}{E}
$$

Or,

$$
\omega=\Sigma \omega_{i} s_{i}
$$

The results presented in Table 5 indicate that during the regulatory policy regime (with industrialization in focus) intra-sectoral productivity growth contributed around $45 \%$ to overall productivity growth. The rest $55 \%$ contribution came from labour relocation effects. However, as the country shifted to a market led regime and the growth rate accelerated, the contribution of the inter-sectoral productivity /structural change effect diminished rapidly. In the 2000s, it fell to a mere $13 \%$. Apparently, a high GDP growth rate in the 2000s was largely sustained by a progressive increase in intra-sectoral labour productivity. But, the contribution of inter-sectoral changes in employment remained positive implying that in general labour moved from low to higher productivity sectors. These results are in sync with Macmillan and Rodrik (2011) and others. But the existing studies, which are conducted at a point in time fail to capture over time changes in structural dynamics. The present study shows that the contribution of structural change in employment to growth declined drastically and secularly as the country transitioned to a high growth regime driven by globalisation. In what follows, I analyse the employment and productivity effects at the sector level to provide deeper insights on intra- and inter-sectoral productivity effects.

\subsection{Sector-level analysis}

For estimating the contribution of employment and productivity by sector, the aggregate effects are expressed as the sum of sector level effects. Thus, equation 3 can be rewritten as

$$
\frac{\Delta \mathrm{y}}{y}=\Sigma_{i} \overline{\omega_{l} S l} \frac{\Delta \mathrm{y}}{y}+\sum_{i} \bar{e}_{i} \frac{\Delta \mathrm{y}}{y}+\overline{\mathrm{a}} \frac{\Delta \mathrm{y}}{y} \ldots \ldots . .(7)
$$


The above equation is decomposed to estimate the sector level effects (formulas A.6 to A.8 in Appendix). The employment rate, productivity, and structural change effects by sector over time are put together in Table 6 .

\section{Intra sectoral productivity effects}

Table 6 shows that the contribution of intra-sectoral productivity growth to aggregate productivity was highly skewed in favour of agriculture in the 1970s. An exceptionally high productivity contribution of agriculture can be explained by the onset of green revolution during this period. This was also the period when all other sectors exhibited low productivity. The productivity growth effect diminished in agriculture in subsequent phases but that in other sectors it improved significantly. During the 1980s, there was a surge in intra-sectoral productivity growth in manufacturing due to relaxation in the restrictions on domestic capacity creations. But in the 1990s, the service sector productivity growth started catching up with manufacturing, and by 2000s it raced ahead that of the manufacturing sector. As a matter of fact, business, telecommunication, and hotels and trade services dramatically improved their contribution to productivity growth and outpaced that of even manufacturing. Theoretical arguments and empirical evidence indicate that manufacturing is at the core of structural transformation and productivity growth. In India however this sector did not show much productivity dynamism. Its productivity remains lower than that of even 'trade and hotels'. In general, in the growth process business and finance services receive impulses from industry with rising demand for advanced services such as $R \& D$, marketing finance and production. These advanced services then reinforce these impulses and strengthen the industry base. In India however, the growth impulses for dynamic services came from the global markets due to its insertion into global service value chains and therefore had little productivity enhancing 
effects on other sectors, including manufacturing. The outcome is a sharp rise in productivity effect differentials across sectors. The coefficient of variation in productivity effects increased from $44 \%$ to over $100 \%$ as the economy transitioned to a market regime (Table 6). Instead of convergence in productivity, there is a growing divergence.

Table 6: Decomposition of GDP growth per capita by sector (\%)

\begin{tabular}{|c|c|c|c|c|c|c|c|c|c|c|c|c|}
\hline & \multicolumn{4}{|c|}{ Employment rate effect } & \multicolumn{4}{|c|}{$\begin{array}{l}\text { Inter-sectoral productivity } \\
\text { effect }\end{array}$} & \multicolumn{4}{|c|}{$\begin{array}{l}\text { Intra-sectoral } \\
\text { productivity effects }\end{array}$} \\
\hline & $\begin{array}{l}1972- \\
83\end{array}$ & $\begin{array}{l}1983- \\
94\end{array}$ & $\begin{array}{l}1994 \\
-05\end{array}$ & $\begin{array}{l}2005- \\
12\end{array}$ & $\begin{array}{l}1972 \\
-83\end{array}$ & $\begin{array}{l}1983- \\
94\end{array}$ & $\begin{array}{l}1994 \\
-05\end{array}$ & $\begin{array}{l}2005- \\
2012\end{array}$ & $\begin{array}{l}1972 \\
-83\end{array}$ & $\begin{array}{l}1983 \\
-94\end{array}$ & $\begin{array}{l}1994 \\
-05\end{array}$ & $\begin{array}{l}200 \\
5-12\end{array}$ \\
\hline Agriculture & -23.3 & -17.7 & -17.2 & -16.6 & 10.8 & 9.3 & 10.3 & 11.6 & 30.4 & 13,5 & 9.8 & 13.7 \\
\hline Mining & 0.8 & 0.3 & -0.3 & 0 & 3.2 & 1.2 & -11 & -0.1 & 0.9 & 2.9 & 3.6 & 1.3 \\
\hline Manufacturing & 7.4 & -0.1 & 3.5 & 0.8 & 3.5 & 0 & 1 & 0.2 & 6.6 & 14.3 & 11.7 & 18.5 \\
\hline Utilities & 0.5 & 0.5 & -0.3 & 0.6 & 2.8 & 2.1 & -1.7 & 2.4 & -0.3 & 1.8 & 3.9 & -1.1 \\
\hline Construction & 1.7 & 3.8 & 5.3 & 11.1 & 4.4 & 5.6 & 3.3 & -0.4 & -4 & -3.2 & 0.8 & -1.1 \\
\hline Trade \&Hotels & 5.2 & 4.7 & 7.1 & 0.2 & 5.2 & 3.6 & 3.9 & 0.1 & 4.9 & 6.3 & 10.7 & 21.2 \\
\hline $\begin{array}{l}\text { Transport \& } \\
\text { telecommunications }\end{array}$ & 3 & 1.5 & 2.6 & 1.7 & 3.5 & 1.4 & 2.6 & 1.9 & 1.4 & 4.3 & 8.1 & 12.6 \\
\hline $\begin{array}{l}\text { Finance. Real estate } \\
\text { and Business } \\
\text { Services }\end{array}$ & 1.3 & 0.5 & 1.6 & -0.1 & 16.4 & 6.2 & 15.3 & -1 & -5.7 & 20.4 & 0.2 & 28.3 \\
\hline Community services & 2.3 & 6.4 & -3.1 & 2.6 & 1.5 & 3.1 & -1.7 & 1.3 & 7.6 & 7.4 & 19.2 & 9.7 \\
\hline
\end{tabular}

Source: Author's estimates based on the selected NSS Rounds

\section{Employment rate effects}

Assuming that the total growth in employment is the sum of employment generation in each sector, the amount of growth in output per capita that can be linked to changes in the share of employment of a sector is worked out using formula number A.8 in the appendix. The results presented in Table 6 show that there has been a continuous shift of labour away from the primary to non-primary sectors. Thus, a negative employment rate effect in agriculture has been accompanied with a positive one across most other sectors. During the policy regime of the 1970s, the employment 
rate effect was almost equally distributed across the secondary (10.4\%) and tertiary sectors $(11.8 \%)$ due to strong inter-sectoral linkages. In this phase, the manufacturing sector expanded and created demand for services of various kinds, which were both complementary and ancillary to industrial activities. As a result, along with industry, the total employment in services also tended to rise (as proposed by Kaldor, 1968, p. 387). In the successive periods (or regimes) however, this relationship started breaking up. In the 1980s, as the economy opened up, there was a sudden jump in the employment growth in services. The secondary sector employment rate effect declined sharply from $10.4 \%$ in the 1970 s to $4.5 \%$ between 1983 and $1993-94$ while that of the service sector increased from $11.8 \%$ to $13.1 \%$ over the same period. But, growth in the service sector employment could not be sustained in the 1990s; it declined to $8.2 \%$. Construction, hotels and trade, and to some extent manufacturing propelled employment. In the 2000 s, when there was explosion in service value added, the employment rate effect in this sector further declined to $4.4 \%$. Clearly, economic growth driven by dynamic service sectors could not absorb labour released from agriculture. Considering that the share of manufacturing in GDP remained stagnant, there was no appreciable expansion in manufacturing or ancillary service employment either. Where was labour released from agriculture headed to then? It was largely absorbed in construction, which emerged as the single largest employment-absorbing sector in the 2000s. Nearly two-thirds of the nonagricultural employment rate effect was due to job creation in this sector. As seen above, this sector is a low productivity sector in the Indian context with intra sectoral productivity growth being negative in this sector. This means that the increase in employment in this sector has had a negative inter-sectoral productivity effect on aggregate productivity effect. This phenomenon could be partly explained by the employment guarantee programme MNREGA which created employment in low value added construction activities on a large scale. 


\section{Inter-sectoral productivity effect}

While examining these effects by sector in Table 6, I find that relocation of labour from agriculture to other sectors has had a productivity enhancing effect on agriculture itself. Interestingly, this effect has been growing over time. It indicates that there is still a large surplus of labour in the form of "disguised unemployment" trapped in agriculture in India which needs to be withdrawn from there (For discussion, Kaldor, 1968, p. 386). But unfortunately, the productivity contribution of the movement of labour to other sectors, though positive, has been diminishing over time. It could be attributed to three factors. One, there are few opportunities for labour force to get absorbed in high productivity sectors. While the share of manufacturing is almost stagnated, dynamic services are not generating job opportunities. Employment opportunities are created in the low productivity construction sector which lead to structural retrogression in employment and hence a decline in the inter-sectoral productivity growth effect. Two, the rate of labour relocation from agriculture itself has slowed down because there have been few opportunities for labour to get absorbed in non-primary sectors. Three, the inter-sectoral productivity effects relative to employment rate effects have been declining over time across all sectors except business and finance (not shown here). It indicates that labour relocation has essentially been to low productivity segments in most sectors.

Even if at the aggregate level structural bonus turns out to be positive, over time analysis indicates that this is sharply disappearing. The sector level analysis indicates that employment opportunities are not being created in high productivity sectors and segments. Thus a vast population is still in vulnerable employment that cannot be qualified as productive employment. Intra sectoral productivity levels have grown but there is a large potential of further growth in these levels. 


\section{Policy implications}

Using the Job Generation and Decomposition (JoGGs) tool of the World Bank, this paper sets out to establish the link between economic growth, employment and structural change in India in 4 different policy phases from 1972 to 2012, . The analysis confirms that there has been acceleration in growth, which is also accompanied by a shift in the structure of the value-added in the Indian economy. However this is not accompanied by commensurate changes in the employment structure. Post liberalization, economic specialisation of national economies within global value chains has weakened internal inter-sectoral linkages affecting the process of economic and labour market restructuring. Productivity growth is driven by dynamic export oriented IT and IT related services. With little 'connectedness' of these services with other sectors, they operate as 'high productivity enclaves' generating few jobs. Not only that they create 'resource curse' like situation by pushing the general wage rates up. There are no market-based mechanisms to generate spillover effects on other sectors. As a result, a large chunk of labour remains stuck in low productivity sectors. The contribution of structural change in employment to productivity growth is therefore vanishing over time. The diminishing 'structural bonus' seems to have impeded the generation of productive employment and, in turn, poverty reducing effects of growth. Further, productivity of manufacturing remains lower than that of the service sector, which is contrary to the expectations. The sector appears to have hit the bottlenecks due to market failures in credit, labour, product and knowledge markets, and government failures in addressing these failures through good governance, efficient tax system and good infrastructure. Productivity contributions of other sectors have been on decline. Their expansion does not commensurate with the fast growing sectors. 
These results highlight the need for an ambitious complementary policy agenda to leverage engagement in trade. This requires government intervention to broad base the process of structural transformation for generating 'productive employment'. There is an urgent need to develop domestic capabilities in agriculture and industry and intervene directly in the labour market to promote human resources. This calls for an integrated portfolio of public policies with competitiveness, quality improvements, technology, skill up- gradation, and innovations across all sectors along with rural diversification as the core themes. Demand stimulation will work as leverage for increasing investments and productivity to stimulate product markets. On the supply side, a comprehensive "employment policy" will have to be adopted with transformational changes in education, promotion of entrepreneurship, and effective labour market management as pillars to promote human capital. These policies need to be judiciously combined with macroeconomic policies. Globalisation has thus increased the need for government interventions rather than reduced it. A well-designed strategic intervention is the only way forward to fast track the growth process in developing countries.

\section{References}

Aggarwal, A. (2001) Technology policies and acquisition of technological capabilities in the industrial sector: A comparative analysis of the Indian and Korean experiences. Science Technology \& Society, 6(2), 255-304.

Aggarwal, A., \& Kumar, N. (2012). Structural change, industrialization and poverty reduction: the case of India, UNESCAP-SSWA Development Papers 1206, New Delhi

Alvarez-Cuadrado, F. N.V.Long and M. Poschke (2017) Capital-labor Substitution, Structural Change, and Growth , Theoretical Economics 12 (2017):1229-1266

Baumol, W. J. (1967) Macroeconomics of unbalanced growth: the anatomy of urban crisis. The American Economic Review, 415-426.' 
Bbaale, E. (2013). 'Is Uganda's Growth Profile Jobless?'. International Journal of Economics and Finance, 5(11): 105.

Bernard, A. B., \& Jones, C. I. (1996) Comparing apples to oranges: productivity convergence and measurement across industries and countries. The American Economic Review, 1216-1238.

Bhalla, Surjit and Kaur, Ravinder (2011) Labour force participation of women in India: some facts, some queries. Working Paper, 40. Asia Research Centre, London School of Economics and Political Science, London, UK.

Boserup, E (1970) Woman's Role in Economic Development London: George Allen and Unwin Ltd, 1970.

Byiers, B., T. Berliner, F. Guadagno, and L.R. Takeuchi (2015). 'Working for Economic Transformation’. ODI Dimension Paper 03. London: Overseas Development Institute.

Chenery, H.B. and L.J. Taylor (1968). "Development Patterns: Among Countries and Over Time," Review of Economics and Statistics, 50: 391-416.

De Vries, G. J. (2010). Small Retailers in Brazil: Are Formal Firms Really More Productive?. The Journal of Development Studies, 46(8), 1345-1366.

Gouyette, C., \& Perelman, S. (1997) Productivity convergence in OECD service industries. Structural Change and Economic Dynamics, 8(3), 279-295.

Ghani, E., and S.D. O'Connell (2014). 'Can Service be a Growth Escalator in Low-Income Countries?'. Policy Research Working Paper No. 6971. Washington, DC: World Bank Group

Gutiérrez, C., Orecchia, C., Paci, P. and Serneels, P. (2009) 'Does Employment Generation Really Matter for Poverty Reduction?' in Kanbur R. and Svejnar, J. (eds) 'Labor Markets and Economic Development', New York: Routledge

Hartwig, J. (2012) Testing the growth effects of structural change. Structural Change and Economic Dynamics, 23(1), 11-24

Islam, I. and D. Kucera (2014) Beyond Macroeconomic Stability: Structural Transformation and Inclusive Development, Basingstoke/Geneva: Palgrave

Joshi, P.K., Tewari, Laxmi and Birthal, P.S. (2006) Diversification and its impact on smallholders: Evidence from a study on vegetable production, Agricultural Economics Research Review, 19(2): 219-236

Kaldor N. (1968) Strategic Factors in Economic Development, New York State School of Industrial and Labor relations, Cornell University, Ithaca, NY, USA. 
Kucera, D., \& Roncolato, L. (2012). Structure matters.: Sectoral drivers of growth and the labour productivity-employment relationship, ILO Research Paper No.3, December 2012. International Labour Office

Hull, K. (2009). 'Understanding the Relationship between Economic Growth, Employment and Poverty Reduction'. In OECD Publication Promoting Pro-Poor Growth: Employment. Paris: OECD.

Lin, J.Y..( 2011) New Structural Economics : A Framework for Rethinking Development. World Bank Research Observer;26(2), 193-221.

Malunda, D. (2013). 'Employment Intensity of Non-Agricultural Growth in Rwanda: Analyzing the Links between Growth, Employment, and Productivity in Rwanda'. Institute of Policy Analysis and Research (IPAR)-Rwanda Research Paper. Available at:

https://editorialexpress.com/cgi-

bin/conference/download.cgi?db_name=CSAE2013\&paper_id=814 accessed on 5 March 2017

McMillan, M. S., \& Rodrik, D. (2011) Globalization, structural change and productivity growth ,NBER working paper 17143. National Bureau of Economic Research.

Naudé W.,A. Szirmai; N.Haraguchi. (2015) Structural Change and Industrial Development in the BRICS. red. / Oxford : Oxford University Press, 2015

Nordhaus, W. D. (2008) Baumol's diseases: a macroeconomic perspective. The B.E. Journal of Macroeconomics, 8(1):1-39

OECD (2015) Trade Policy Implications of Global Value Chains, Trade and Agriculture Directorate, OECD, Paris, accessed on 13 October 2017 from https://www.oecd.org/tad/tradepolicy-implications-gvc.pdf

Rodrik, Dani (2011), “Unconditional Convergence,” CEPR Discussion Paper 8631, November.

Timmer M.P. and A. Szirmai (2000) Productivity growth in Asian manufacturing: the structural bonus hypothesis examined, Structural Change and Economic Dynamics, 11(4): 371-392,

Triplett, J. E., \& Bosworth, B. (2003) Productivity measurement issues in services industries: Baumol's disease has been cured. Economic Policy Review, 9(3), 22-33.

UNCTAD (2004), Export of services and economic growth in developing countries UNCTAD/DITC/TNCD/MISC/2003/6, United Nations Conference on Trade and Development

Uy T. , Kei-Mu Yi, J. Zhang (2013) Structural change in an open economy, Journal of Monetray Economics, 60(6): 667-682 
Van Ark B, Timmer M (2000) Asia's Productivity Performance and Potential at the Turn of the Century: An international Perspective. Working Paper, University of Groningen \& Conference Board, 2000.

Van Ark, B., \& McGuckin, R. H. (1999). International comparisons of labor productivity and per capita income. Monthly Labour Review: July 1999.

Virmani, A (2005) Institutions, Governance and Policy Reform: A Framework for Analysis, Economic and Political Weekly, 40 (22): 2341-235.

\section{APPENDIX}

\section{Shapley's decomposition of GDP growth per capital into employment and productivity effects: The methodological details}

\section{Step 1: Decomposition of aggregate growth}

The changes in GDP per capita can be decomposed into changes in output per worker, changes in employment rates and changes in the size of the labor force using the following equation:

$$
\Delta y=\bar{\omega}^{*} \Delta y+\bar{e}^{*} \Delta y+\bar{a} * \Delta y
$$

\section{Where}

$\overline{\boldsymbol{\omega}}$ is the fraction of growth that can be linked to changes in output per worker such that,

$$
\bar{\omega} \equiv \Delta \omega\left[\frac{e_{t=1} a_{t=1}+e_{t=0} a_{t=0}}{3}+\frac{e_{t=1} a_{t=0}+e_{t=0} a_{t=1}}{6}\right] / \Delta y
$$

$\overline{\mathbf{e}}$ is the $\mathbf{w}$ is the fraction of growth that can be linked to changes in employment rate such that,

$$
\bar{e} \equiv \Delta e\left[\frac{\omega_{t=1} a_{t=1}+\omega_{t=0} a_{t=0}}{3}+\frac{\omega_{t=1} a_{t=0}+\omega_{t=0} a_{t=1}}{6}\right] / \Delta y
$$

$\overline{\mathbf{a}}$ is the fraction of growth that can be linked to changes in labour participation rate such that,

$$
\bar{a} \equiv \Delta a\left[\frac{\omega_{t=1} e_{t=1}+\omega_{t=0} e_{t=0}}{3}+\frac{\omega_{t=1} e_{t=0}+\omega_{t=0} e_{t=1}}{6}\right] / \Delta y
$$

\section{Decomposition of productivity effects}

Contribution of changes in output per worker within sectors: It's the contribution of within sector changes 
in output per worker to total changes in output per worker times the contribution of aggregate output per worker to GDP per capita

$$
\begin{aligned}
\bar{\omega}_{w} & =\bar{\omega}_{w}^{\omega} * \bar{\omega} \\
& =\left[\left(\sum_{i=1}^{S} \Delta \omega_{i} *\left(\frac{s_{i, t=0}+s_{i, t=1}}{2}\right)\right) / \Delta \omega\right] * \bar{\omega}
\end{aligned}
$$

where $\mathrm{s}$ is the share of the sector in total employment.

Contribution of intersectoral employment shifts: It's the contribution of between sector changes in output per worker to total changes in output per worker times the contribution of aggregate output per worker to GDP per capita

$$
\begin{aligned}
\bar{\omega}_{B} & =\bar{\omega}_{B}^{\omega} * \bar{\omega} \\
& =\left[\sum_{i=1}^{S} \Delta s_{i} *\left(\frac{\omega_{i, t=0}+\omega_{i, t=1}}{2}\right) / \Delta \omega\right] * \bar{\omega}
\end{aligned}
$$

2. Decomposition at the sector level

Within changes in output per worker in sector $i$ : It is the contribution of sector i's, within sector change in output per worker to total changes in output per worker times the contribution of output per worker to changes in per capita GDP.

$$
\begin{aligned}
\bar{\omega}_{i} & =\bar{\omega}_{i}^{\omega} * \bar{\omega} \\
& =\left(\Delta \omega_{i} *\left(\frac{s_{i, t=0}+s_{i, t=1}}{2}\right) / \Delta \omega\right) * \bar{\omega}
\end{aligned}
$$

Contribution of shifts in the share of employment witnessed by sector $i$ : It is the contribution of sector $\mathrm{i}$, to the between sector component of changes in output per worker times the contribution of the between employment shifts component to total GDP per capita

$$
\begin{aligned}
\bar{s}_{i} & =\bar{s}_{i}^{\omega_{B}} * \bar{\omega}_{B} \\
& =\left[\Delta s_{i}\left(\frac{\omega_{i, t=0}+\omega_{i, t=1}}{2}-\frac{\omega_{t=0}+\omega_{t=1}}{2}\right) / \Delta \omega_{B}\right] * \bar{\omega}_{B}
\end{aligned}
$$

Contribution of increases in sectoral employment : contribution of changes in employment in sector i to total employment rate changes times the contribution of employment rate changes to changes in total GDP per capita

$$
\begin{aligned}
\bar{e}_{i} & =\bar{e}_{i}^{e} * \bar{e} \\
& =\left[\Delta e_{i} / \Delta e\right]^{*} \bar{e}
\end{aligned}
$$

